University for Business and Technology in Kosovo

UBT Knowledge Center

UBT International Conference

2017 UBT International Conference

Oct 28th, 2:30 PM - 4:00 PM

\title{
Determination of Aerobic Mesophilic Bacteria and Coliforms in Rar Milk in the Region of Pristhtina, Lipjan and Rahovec
}

\author{
Hyzer Rizani \\ University for Business and Technology \\ Besart Jashari \\ Agency for Food and Veterinary, Prishtine-Kosovo \\ Shkumbin Shala \\ University for Business and Technology, shkumbin.shala@ubt-uni.net \\ Magbule Rizani \\ University for Business and Technology \\ Erna Sopa \\ University for Business and Technology
}

See next page for additional authors

Follow this and additional works at: https://knowledgecenter.ubt-uni.net/conference

Part of the Food Science Commons

\section{Recommended Citation}

Rizani, Hyzer; Jashari, Besart; Shala, Shkumbin; Rizani, Magbule; Sopa, Erna; Gashi, Donjeta; Sahiti, Miranda; and Hoti, Fitore, "Determination of Aerobic Mesophilic Bacteria and Coliforms in Rar Milk in the Region of Pristhtina, Lipjan and Rahovec" (2017). UBT International Conference. 154.

https://knowledgecenter.ubt-uni.net/conference/2017/all-events/154

This Event is brought to you for free and open access by the Publication and Journals at UBT Knowledge Center. It has been accepted for inclusion in UBT International Conference by an authorized administrator of UBT Knowledge Center. For more information, please contact knowledge.center@ubt-uni.net. 


\section{Presenter Information}

Hyzer Rizani, Besart Jashari, Shkumbin Shala, Magbule Rizani, Erna Sopa, Donjeta Gashi, Miranda Sahiti, and Fitore Hoti 


\title{
DETERMINATION OF AEROBIC MESOPHILIC BACTERIA AND COLIFORMS IN RAW MILK IN THE REGION OF PRISHTINA, LIPJAN AND RAHOVEC
}

\author{
Hyzer Rizani ${ }^{1}$, Besart Jashari ${ }^{2}$, Shkëlzim Ukaj ${ }^{1}$, Naser Kamberi ${ }^{1}$, Shkumbin Shala ${ }^{1}$, \\ Magbule Rizani ${ }^{1}$, Erna Sopa ${ }^{1}$, Donjeta Gashi ${ }^{1}$, Miranda Sahiti ${ }^{1}$, Albulena Tasholli ${ }^{1}$ \\ ${ }^{1}$ UBT - Higher Education Institution, Lagjja Kalabria, 10000 p.n., Prishtine, \\ Kosovo \\ ${ }^{2}$ The Agency of Food and Veterinary, Prishtinë-Kosovë \\ shkumbin.shala@ubt-uni.net
}

\begin{abstract}
The microbiological quality of raw milk is key to the quality production of dairy products. Alternation is a term that describes the change of composition, taste and smell at those points where it is inedible for the consumer. Microbial alternation of milk often involves degradation of proteins, carbohydrates and fats of organisms and their enzymes. Milk and dairy consumption has increased considerably in Kosovo over the last decade, and a large part of local production comes from small-scale distributors across the country. In this research, 50 milk samples were taken at some of the cumulative sites and from dairy farms in three Kosovo municipalities (Prishtina, Lipjan and Rahovec). The microbiological quality of the milk samples is analyzed according to official standards. Further, in raw milk, a number of aerobic mesophilic bacteria and number of coliforms were analyzed. Aerobic mesophilic bacteria in fresh milk, used as raw material, did not show more than $2.0 \times 10^{6} \mathrm{cfu} / \mathrm{ml}$, whereas coliforms were presented at 4 $\mathrm{cfu} / \mathrm{ml}$
\end{abstract}

Keywords: milk, mesophilic, aerobic, coliform, cfu.

\section{INTRODUCTION}

Milk is an ideal environment, with a high content of water, enough nutritional elements and an almost neutral $\mathrm{Ph}(\mathrm{Ph} 6,4-6,8)$ that favorites the growth of many microorganisms. Microorganisms in milk can be classified in two main groups: pathogens and responsible microorganisms of the demolition and some of them can play a multiple role (ex. Bacillus cereus). Pathogens microorganisms represent a threat to public health. Due to their enzymes (ex. proteases, peptidase, lipase, esterase, oxidase, polymerase, $\beta$-galaktozidaza,) responsible microorganisms of demolition are able to hydrolyzate the ingridients of milk, such as protein, fat and lactose appropriately, to gain neccesary ingridients for their growth(Andrews, A.T., Anderson, M.\&Goodenough, P.W. (1987). Such reactions can cause demolition of milk that may be accompained by a change of smell, taste and changes in the quality and view of milk(Frank\&Hassan,2003). Microorganisms are spread mainly in dirty environments of farm in milk (ex. faeces, straw chessis and earth. Absorbing microorganisms of the outside can enter in the canal channel and can cause mastitis(Makovec \& Ruegg, 2003). As a conclusion, we can say that the contamination resources are inadequacy of cleanliness of milking equipment, which then can pass in milk(Chambers, 2002). 


\section{METHODS AND MATERIALS}

50 samples were taken in some selling points in Prishtina, Rahovec and Lipjan. Just after getting the samples, they were placed in the conveyor freezer, and we are assured that until the sample is mixed and in full homogeneity. Then, as amount of $30 \mathrm{ml}$ of milk was transferred in a facetious way. For every sample we have used a test tube. The samples were transferred in $0-4^{0} \mathrm{C}$ temperature until they were brought to the laboratory.

Methods of examination of aerobic mesophile bacteriais based in ISO- 4832-1:2013. Microbiology of food chain- Horizontal methods of counting the microorganisms. First part: counting in $30^{\circ} \mathrm{C}$ through pouring technique and the method of Coliforms ISO 4832:2006. The microbiology of food and animal food products-Horizontal method of counting the coliformsCounting technique.

2 plates of Petrit were taken for the counting of aerob mesophiles. The transfer is made for each steril pipette from $1 \mathrm{ml}$ of sample. Only critical dillutions were taken for inoculin in the plate of Pjetrit, to develop a colony between $150-300$ per plate. For the nutritional area was used plate count approximately $12-15 \mathrm{ml}$ in a temperature of $44-47^{\circ} \mathrm{C}$ in each plate. The duration from the moment of preparation of the initial dilution to pouring of the nutritious terrain in plates, no more than 45 min were needed.

Carefully, the plates were mixed and are left in rigid horizontal positions until they are hardened. the plates are incubated in a temperature of $30{ }^{\circ} \mathrm{C} \pm 1{ }^{\circ} \mathrm{C}$ for $72 \mathrm{~h} \pm 3 \mathrm{~h}$.

The counting of colonies is made like this, plates with more than 15 colonies and less than 300 colonies were counted.

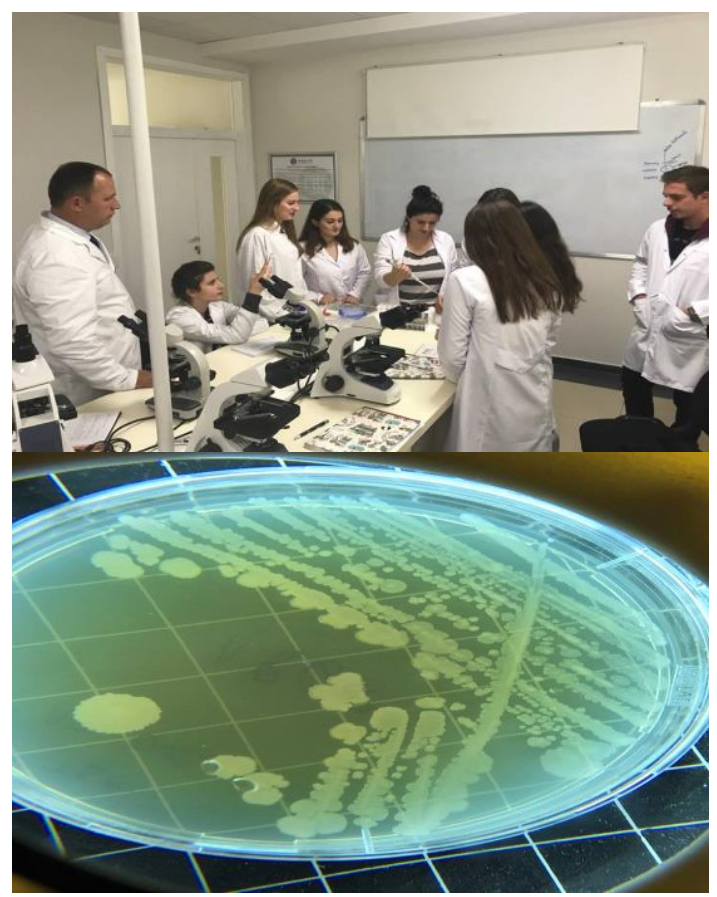

Fig. 1. Work in the Microbiology Laboratory 
After the incubation, a counting for specific colonies was made using the calculator.

For the counting of coliforms was used a hardened nutritional terrain, Crystal violet neutral red bile lactose (VRBL) agar. The microbiology of food and animal food- The preparation of samples, dry or liquid slurry, Incubator, Plates of Pjetrit, 90mm, Pipetor, 1ml, aquatic baths, counter of colonies, tube tests, Durham Tubes, lab bottles, $\mathrm{pH}$-meter, Eza from platinum - iridium or nicel-crome, approxiamately $3 \mathrm{~mm}$ per diameter, or eza for one use.

2 plates were taken, where the tested material is transferred by a steril pipette $1 \mathrm{ml}$ from the corresponding dillution, in the center of each plate. Then, $15 \mathrm{ml}$ of VRBLA were thrown in a temperature of $44^{\circ} \mathrm{C}-47^{\circ} \mathrm{C}$ in each Pjetri plate.

After the complete hardening, $4 \mathrm{ml}$ of the VRBLA terrain were thrown in $44^{\circ} \mathrm{C}$ to $47^{\circ} \mathrm{C}$, on the surface of inoculated terrains. After the hardening, the plates were inacubated in $37^{\circ} \mathrm{C}$ per $24 \mathrm{~h} \pm$ $2 \mathrm{~h}$. After the appointed period of inacubation, the plates of Petrit with more than 10 colonies and less than 150 colonies were taken for counting. The counting was made using the counting equipment of colonies, the colonist in red with a diameter at least $0 / 5 \mathrm{~mm}$ (sometimes surrounded from the red precipated zones. The confirmation was made by pointing 5 typical colonies, in a liquid areaBriliant green lactose, incubated in $37^{\circ} \mathrm{C}$ per $24 \mathrm{~h} \pm 2 \mathrm{~h}$ temperature.

Only the colonies that formed gas in Durham tubes were counted.

The formula for the counting of bacterial colonies is like this:

$$
\Sigma \mathrm{C}
$$

$$
\mathrm{N}=-------------------\mathrm{x} \mathrm{d} V \mathrm{x}\left(\mathrm{n}_{1} \times 0.1+\mathrm{n}_{2}\right)
$$

$* \mathrm{~N}$ - the number of microorganisms in 1 gr sample

$* \Sigma \mathrm{C}-$ the amount of microorganisms in counted plates

*n1 - the number of plates in the intitial dillution

$* \mathrm{n} 2-$ the number of plates in the second dillution

$* d-$ the dillution factor

\section{RESULTS AND DISCUSSION}

In the table below, are given data for microbiological incubators of every type of fredh milk, of each sample through development. The data are the average values of analyzed samples during this study for mesophile bacterias and coliforms in fresh milk. Generally, inside the analyzed type of milk could have been big deviations of measured values. 
Table 1: The general number of mesophile bacterias and coliforms in fresh milk in the regions of Prishtina, Rahovec and Lipjan.

\begin{tabular}{|c|c|c|}
\hline $\begin{array}{l}\text { The } \\
\text { sampling } \\
\text { region }\end{array}$ & $\begin{array}{l}\text { The average of } \\
\text { mesophile aerob } \\
\text { bacteria }\end{array}$ & $\begin{array}{l}\text { The average } \\
\text { number of } \\
\text { coliforms }\end{array}$ \\
\hline Prishtinë & $1.54 \times 10^{6} \mathrm{cfu} / \mathrm{ml}$ & $2 \mathrm{cfu} / \mathrm{ml}$ \\
\hline Prishtinë & $1.8 \times 10^{6} \mathrm{cfu} / \mathrm{ml}$ & $1 \mathrm{cfu} / \mathrm{ml}$ \\
\hline Prishtinë & $2.78 \times 10^{6} \mathrm{cfu} / \mathrm{ml}$ & $5 \mathrm{cfu} / \mathrm{ml}$ \\
\hline Prishtinë & $1.5 \times 10^{6} \mathrm{cfu} / \mathrm{ml}$ & $1 \mathrm{cfu} / \mathrm{ml}$ \\
\hline Prishtinë & $1.51 \times 10^{5} \mathrm{cfu} / \mathrm{ml}$ & $2 \mathrm{cfu} / \mathrm{ml}$ \\
\hline Prishtinë & $1.7 \times 10^{7} \mathrm{cfu} / \mathrm{ml}$ & $1 \mathrm{cfu} / \mathrm{ml}$ \\
\hline Prishtinë & $1.53 \times 10^{6} \mathrm{cfu} / \mathrm{ml}$ & $8 \mathrm{cfu} / \mathrm{ml}$ \\
\hline Prishtinë & $3.2 \times 10^{5} \mathrm{cfu} / \mathrm{ml}$ & $5 \mathrm{cfu} / \mathrm{ml}$ \\
\hline Prishtinë & $2.4 \times 10^{6} \mathrm{cfu} / \mathrm{ml}$ & $2 \mathrm{cfu} / \mathrm{ml}$ \\
\hline Prishtinë & $2.17 \times 10^{5} \mathrm{cfu} / \mathrm{ml}$ & $6 \mathrm{cfu} / \mathrm{ml}$ \\
\hline Prishtinë & $2.1 \times 10^{6} \mathrm{cfu} / \mathrm{ml}$ & $6 \mathrm{cfu} / \mathrm{ml}$ \\
\hline Prishtinë & $1.15 \times 10^{6} \mathrm{cfu} / \mathrm{ml}$ & $1 \mathrm{cfu} / \mathrm{ml}$ \\
\hline Prishtinë & $1.82 \times 10^{7} \mathrm{cfu} / \mathrm{ml}$ & $5 \mathrm{cfu} / \mathrm{ml}$ \\
\hline Prishtinë & $2.95 \times 10^{5} \mathrm{cfu} / \mathrm{ml}$ & $5 \mathrm{cfu} / \mathrm{ml}$ \\
\hline Prishtinë & $1.05 \times 10^{6} \mathrm{cfu} / \mathrm{ml}$ & $1 \mathrm{cfu} / \mathrm{ml}$ \\
\hline Prishtinë & $1.2 \times 10^{7} \mathrm{cfu} / \mathrm{ml}$ & $5 \mathrm{cfu} / \mathrm{ml}$ \\
\hline Prishtinë & $1.9 \times 10^{7} \mathrm{cfu} / \mathrm{ml}$ & $1 \mathrm{cfu} / \mathrm{ml}$ \\
\hline Average & $1.90 \times 10^{6} \mathrm{cfu} / \mathrm{ml}$ & $3.35 \mathrm{cfu} / \mathrm{ml}$ \\
\hline $\begin{array}{l}\text { The } \\
\text { sampling } \\
\text { region }\end{array}$ & $\begin{array}{c}\text { The average of } \\
\text { mesophile aerob } \\
\text { bacteria }\end{array}$ & $\begin{array}{l}\text { The average } \\
\text { number of } \\
\text { coliforms }\end{array}$ \\
\hline Rahovec & $2.6 \times 10^{5} \mathrm{cfu} / \mathrm{ml}$ & $1 \mathrm{cfu} / \mathrm{ml}$ \\
\hline Rahovec & $3.2 \times 10^{7} \mathrm{cfu} / \mathrm{ml}$ & $1 \mathrm{cfu} / \mathrm{ml}$ \\
\hline Rahovec & $2.9 \times 10^{6} \mathrm{cfu} / \mathrm{ml}$ & $6 \mathrm{cfu} / \mathrm{ml}$ \\
\hline Rahovec & $2.5 \times 10^{5} \mathrm{cfu} / \mathrm{ml}$ & $9 \mathrm{cfu} / \mathrm{ml}$ \\
\hline Rahovec & $1.3 \times 10^{7} \mathrm{cfu} / \mathrm{ml}$ & $9 \mathrm{cfu} / \mathrm{ml}$ \\
\hline Rahovec & $3.2 \times 10^{6} \mathrm{cfu} / \mathrm{ml}$ & $2 \mathrm{cfu} / \mathrm{ml}$ \\
\hline Rahovec & $1.55 \times 10^{5} \mathrm{cfu} / \mathrm{ml}$ & $3 \mathrm{cfu} / \mathrm{ml}$ \\
\hline Rahovec & $2.7 \times 10^{6} \mathrm{cfu} / \mathrm{ml}$ & $5 \mathrm{cfu} / \mathrm{ml}$ \\
\hline Rahovec & $4.2 \times 10^{7} \mathrm{cfu} / \mathrm{ml}$ & $1 \mathrm{cfu} / \mathrm{ml}$ \\
\hline Rahovec & $3.2 \times 10^{5} \mathrm{cfu} / \mathrm{ml}$ & $8 \mathrm{cfu} / \mathrm{ml}$ \\
\hline Rahovec & $2.8 \times 10^{6} \mathrm{cfu} / \mathrm{ml}$ & $1 \mathrm{cfu} / \mathrm{ml}$ \\
\hline Rahovec & $1.33 \times 10^{6} \mathrm{cfu} / \mathrm{ml}$ & $2 \mathrm{cfu} / \mathrm{ml}$ \\
\hline Rahovec & $2.9 \times 10^{7} \mathrm{cfu} / \mathrm{ml}$ & $8 \mathrm{cfu} / \mathrm{ml}$ \\
\hline Rahovec & $2.8 \times 10^{5} \mathrm{cfu} / \mathrm{ml}$ & $2 \mathrm{cfu} / \mathrm{ml}$ \\
\hline Rahovec & $3.3 \times 10^{6} \mathrm{cfu} / \mathrm{ml}$ & $5 \mathrm{cfu} / \mathrm{ml}$ \\
\hline Rahovec & $2.52 \times 10^{6} \mathrm{cfu} / \mathrm{ml}$ & $1 \mathrm{cfu} / \mathrm{ml}$ \\
\hline Rahovec & $1.2 \times 10^{7} \mathrm{cfu} / \mathrm{ml}$ & $5 \mathrm{cfu} / \mathrm{ml}$ \\
\hline Average & $2.60 \times 10^{6} \mathrm{cfu} / \mathrm{ml}$ & $4.06 \mathrm{cfu} / \mathrm{ml}$ \\
\hline
\end{tabular}




\begin{tabular}{lll}
\hline $\begin{array}{l}\text { The } \\
\text { sampling } \\
\text { region }\end{array}$ & $\begin{array}{c}\text { The average of } \\
\text { mesophile aerob } \\
\text { bacteria }\end{array}$ & $\begin{array}{c}\text { The average } \\
\text { number of } \\
\text { coliforms }\end{array}$ \\
\hline Lipjan & $4.9 \times 10^{5} \mathrm{cfu} / \mathrm{ml}$ & $0 \mathrm{cfu} / \mathrm{ml}$ \\
Lipjan & $1.5 \times 10^{5} \mathrm{cfu} / \mathrm{ml}$ & $7 \mathrm{cfu} / \mathrm{ml}$ \\
\hline Lipjan & $1.6 \times 10^{5} \mathrm{cfu} / \mathrm{ml}$ & $1 \mathrm{cfu} / \mathrm{ml}$ \\
\hline Lipjan & $2.0 \times 10^{5} \mathrm{cfu} / \mathrm{ml}$ & $6 \mathrm{cfu} / \mathrm{ml}$ \\
\hline Lipjan & $2.1 \times 10^{5} \mathrm{cfu} / \mathrm{ml}$ & $2 \mathrm{cfu} / \mathrm{ml}$ \\
\hline Lipjan & $1.0 \times 10^{5} \mathrm{cfu} / \mathrm{ml}$ & $6 \mathrm{cfu} / \mathrm{ml}$ \\
\hline Lipjan & $1.0 \times 10^{5} \mathrm{cfu} / \mathrm{ml}$ & $8 \mathrm{cfu} / \mathrm{ml}$ \\
\hline Lipjan & $1.2 \times 10^{5} \mathrm{cfu} / \mathrm{ml}$ & $2 \mathrm{cfu} / \mathrm{ml}$ \\
\hline Lipjan & $2.1 \times 10^{5} \mathrm{cfu} / \mathrm{ml}$ & $5 \mathrm{cfu} / \mathrm{ml}$ \\
\hline Lipjan & $1.1 \times 10^{5} \mathrm{cfu} / \mathrm{ml}$ & $6 \mathrm{cfu} / \mathrm{ml}$ \\
\hline Lipjan & $1.6 \times 10^{5} \mathrm{cfu} / \mathrm{ml}$ & $9 \mathrm{cfu} / \mathrm{ml}$ \\
\hline Lipjan & $1.8 \times 10^{5} \mathrm{cfu} / \mathrm{ml}$ & $8 \mathrm{cfu} / \mathrm{ml}$ \\
\hline Lipjan & $1.9 \times 10^{5} \mathrm{cfu} / \mathrm{ml}$ & $6 \mathrm{cfu} / \mathrm{ml}$ \\
\hline Lipjan & $1.8 \times 10^{5} \mathrm{cfu} / \mathrm{ml}$ & $1 \mathrm{cfu} / \mathrm{ml}$ \\
\hline Lipjan & $2.2 \times 10^{5} \mathrm{cfu} / \mathrm{ml}$ & $5 \mathrm{cfu} / \mathrm{ml}$ \\
\hline Lipjan & $3.1 \times 10^{5} \mathrm{cfu} / \mathrm{ml}$ & $1 \mathrm{cfu} / \mathrm{ml}$ \\
\hline Lipjan & $4.8 \times 10^{5} \mathrm{cfu} / \mathrm{ml}$ & $5 \mathrm{cfu} / \mathrm{ml}$ \\
\hline Average & $2.10 \times 10^{6} \mathrm{cfu} / \mathrm{ml}$ & $4.59 \mathrm{cfu} / \mathrm{ml}$ \\
\hline
\end{tabular}

From the gained results we can see that the total bacterial microflorais inside the standard norms in three regions: Prishtina1.90x106 cfu/ml, Rahovec 2.60x106 cfu/ml, Lipjan2.10x106 cfu/ml, and the total average is $2.20 \times 106 \mathrm{cfu} / \mathrm{ml}$. The content of coliform microorganisms is in the described limit from the standard. The high presence of coliforms is found in the region of Lipjan $4.59 \mathrm{cfu} / \mathrm{ml}$, then in Rahovec $4.06 \mathrm{cfu} / \mathrm{ml}$ and in Prishtina $3.35 \mathrm{cfu} / \mathrm{ml}$. In the second year prevails a high load of thermophile bacteria comparing to the content of the bacteria mesophile.

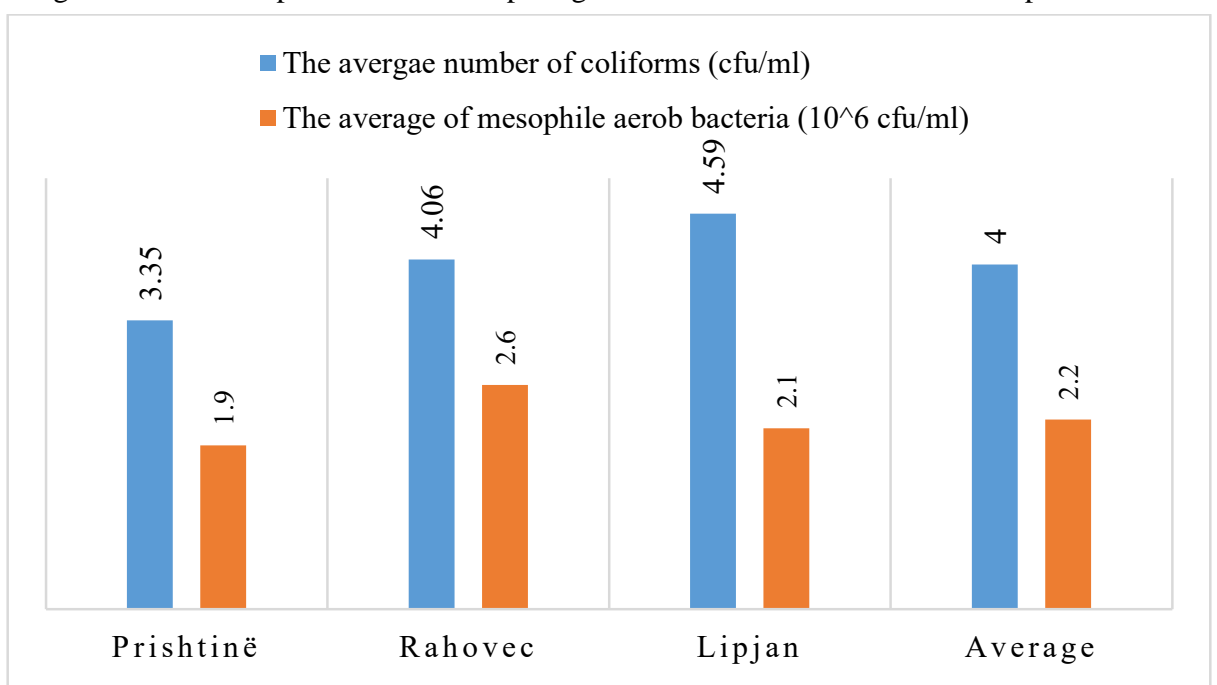

Fig 1: Average of total number of mesophilic bacteria and coliforms in fresh milk in regions of research. 


\section{CONCLUSION}

Bacterial microflora is studied to evaluate the hygiene of production system, before the usage, which then is reflected in the bacterial loads of milk after pasteurization. Every fresh milk tell a total bacterial microflora inside the standard.

During the determination of the number of aerobic mezophilic bacteria in the region of Pristina we have generated this average $1.90 \times 10^{6} \mathrm{cfu} / \mathrm{ml}$, in the region of Rahovec $2.60 \times 10^{6} \mathrm{cfu} / \mathrm{ml}$, and in the region of Lipjan 2.10x106 cfu/ml.

Starting from the content of coliforms that have resulted in each fresh milk, results in a recontamination after usage, telling poor hygiene practices. For this reason, it is recommended maintaining of aspectual conditions in the tubes of processing and packaging lines.

The average number of coliforms in three regions is as below: We have low values in Prishtina3.35 cfu/ml, then in Rahovec we have $4.06 \mathrm{cfu} / \mathrm{ml}$, and an increase in no normal standards in Lipjan $4.59 \mathrm{cfu} / \mathrm{ml}$.

It is recommended to store the unprocessed milk in $2^{\circ} \mathrm{C}$, which has resulted to be effective in the growth of fresh milk life comparing to the store beyond $4^{0} \mathrm{C}$ and $7^{\circ} \mathrm{C}$.

\section{REFERENCES:}

1. Andrews, A.T., Anderson, M. \&Goodenough, P.W. (1987) A study of the heat stabilities of a number of indigenous milk enzymes. Journal of Dairy Research, 54, 237-246.

2. AMILDA BALLATA "Vlerësimi I Parametrave të Cilësisë të Produkteve të Pasterizuar (Qumështi Pasterizuar) Gjatë Periudhës së Ruajtjes "Dizertacion përmarrjen e grades shkencore DOKTOR.

3. FAO/WHO (2003c) The Recommended International Code of Practice General Principles of Food Hygiene CAC/RCP 1 -1969, Revision 4 (2003). In: Food Hygiene Basic Texts, pp. 1-30, Secretariat of the Codex Alimentarius Commission Joint FAO/WHO Food Standards Programme, Rome.

4. FAO (2003) General Principles of Food Hygiene, Vol. 1, 4th revision of the 1969 edition, pp. 31-32, Codex Alimentarius of the Food and Agriculture Organisation of the United Nation Rome.

5. https://www.iso.org/about-us.html.

6. https://www.iso.org/standard/53728.html

7. SI (Statutory Instruments) (1995) Makovec \& Ruegg, 2003 Food Milk and Dairies, The Dairy Products

(Hygiene) Regulations, Statutory Instruments No. 1086, HMSO, London.

8. Shipe, W.F., Bassette, R., Deane, D.D., Dunkley, W.L., Hammond, E.G., Harper, W.J., Kleyn, D.H., Morgan, M.E., Nelson, J.H. \&Scanlan, R.A. (1978) Off flavours of milk: nomenclature, standards and bibliography. Journal of Dairy Science, 61, 855-869. 